DOI: $10.15193 /$ zntj/2016/106/131

\author{
ALINA KAŁUŻEWICZ, JOLANTA LISIECKA, MONIKA GĄSECKA, \\ AGNIESZKA WAŚKIEWICZ, WŁODZIMIERZ KRZESIŃSKI, \\ TOMASZ SPIŻEWSKI , BARBARA FRĄSZCZAK
}

\title{
CHANGES IN COMPOSITION OF PHENOLIC COMPOUNDS AND TOCOPHEROLS IN BROCCOLI HEADS DURING SHORT-TERM STORAGE
}

\begin{abstract}
S u m m a r y
Broccoli (Brassica oleracea L. var. italica) contains numerous biologically active compounds. However, their levels change during processing and storage.

The objective of the research study was to determine the effect of short-term storage $(1 \div 4$ days $)$ of broccoli heads at different temperatures $\left(3{ }^{\circ} \mathrm{C}, 16{ }^{\circ} \mathrm{C}\right.$, and $\left.21{ }^{\circ} \mathrm{C}\right)$ on the contents of phenolic acids, selected flavonoids (quercetin and kaempferol), and tocopherols. Broccoli heads were harvested in autumn when they reached their maximum size and their buds were $2 \mathrm{~mm}$ in diameter.

The content of phenolics and tocopherols depended on the storage time of broccoli heads. The lowest content of phenolics was found immediately after the broccoli was harvested, whereas the highest content thereof was reported after 4 days of storage. However, the storage temperature did not impact the contents of those compounds. In the research study, the content of caffeic acid was reported to be highest in the fresh broccoli heads; the content of sinapic acid was the second-highest, and that of the ferulic acid was the third-highest. The content of kaempferol in the broccoli heads was higher than that of quercetin. No differences were reported in the content of quercetin and kaempferol at particular storage temperatures on every single day of the experiment. An increase was reported only when compared with the control sample (the 0 day of storage). In the broccoli heads, the predominant tocopherol was $\alpha$-tocopherol. The lowest loss in the total tocopherols occurred while storing at a temperature of $3{ }^{\circ} \mathrm{C}$ and the highest: at a temperature of $21^{\circ} \mathrm{C}$
\end{abstract}

Key words: Brassica oleracea L. var. italica, HPLC, phenolics, tocopherols, storage, temperature

Dr A. Kałużewicz, dr J. Lisiecka, dr W. Krzesiński, dr T. Spiżewski, dr B. Fraszczak, Katedra Warzywnictwa, Wydz. Ogrodnictwa i Architektury, Uniwersytet Przyrodniczy w Poznaniu, ul. Dabrowskiego 159, 60-594 Poznań, dr M. Gąsecka, dr hab. A. Waśkiewicz, Katedra Chemii, Wydz. Technologii Drewna, Uniwersytet Przyrodniczy w Poznaniu, ul. Wojska Polskiego 25, 60-625 Poznań.

Kontakt:kalina@up.poznan.pl 


\section{Introduction}

Broccoli (Brassica oleracea L. var. italica) is a vegetable of high nutritional value owing to the abundance of health-promoting phytochemicals therein [1]. The variation among the contents of bioactive components therein depends both on the genetics and the environment including the conditions of growing it and the pre-harvest and/or postharvest conditions [25]. Of all the bioactive compounds, phenolics deserve special attention [1] because of their role in preventing cancer and cardiovascular diseases [3]. Owing to their health-promoting effects, the phenolic compounds were intensively investigated over recent years [29]. Depending on their structure, phenolic compounds may be classified into simple phenols, phenolic acids, hydroxycinnamic acid derivatives, and flavonoids [10].

Phenolic compounds, especially flavonoids, are among the major antioxidants in Brassica vegetables [24]. Many research studies show that broccoli has a very high content of total phenolics [3].

Quercetin and kaempferol are the major flavonoids found in broccoli and they are known to be potent free-radical scavengers and antioxidants [24].

Tocopherols that belonging to lipid-soluble antioxidants are produced only by photosynthetic organisms including all plants, algae, and most cyanobacteria. The composition of tocopherol varies among species and among tissues within one species [14]. Tocopherols have vitamin E activity in mammals, with $\alpha$-tocopherol and $\gamma$-tocopherol exhibiting the greatest effects. The high level of vitamin $\mathrm{E}$ in broccoli is of great importance because of its potential role in preventing heart diseases, cancer, Alzheimer's disease, and other degenerative diseases [14].

Broccoli has a limited shelf life [32]. Many researchers reported a reduction in the amount of bioactive compounds in broccoli during post-harvest handling, processing, and storage $[18,28]$. There are rather limited reference literature data on the changes in the content of flavonoids and tocopherols in broccoli upon storage; they often appear contradictory $[15,18]$.

The objective of the research study was to assess the effect of short-term storage $(1 \div 4$ days $)$ of broccoli heads at different temperatures $\left(3{ }^{\circ} \mathrm{C}, 16^{\circ} \mathrm{C}\right.$, and $\left.21^{\circ} \mathrm{C}\right)$ on the levels of selected phenolic compounds, i.e. phenolic acids and flavonoids (quercetin and kaempferol), as well as tocopherols.

\section{Materials and methods}

\section{Materials}

In 2011, two experiments were conducted on the effect of storage time $(1 \div 4$ days) and temperature $\left(3{ }^{\circ} \mathrm{C}, 16^{\circ} \mathrm{C}\right.$, and $\left.21^{\circ} \mathrm{C}\right)$ on chemical changes in broccoli heads. The first experiment was carried out in a period from the $5^{\text {th }}$ to the $9^{\text {th }}$ of September, 
and the second one from the $19^{\text {th }}$ to $23^{\text {rd }}$ of September. Each combination of the material analyzed consisted of 5 broccoli heads. The analysis included one cultivar, i.e. 'Tiburon'. The heads for the experiments were collected from the broccoli planted on the $7^{\text {th }}$ of July, at its four-leaf stage, and spaced $0.5 \times 0.5 \mathrm{~m}$ from each other. The experiment was established on a podzolic soil, the arable layer of which was loamy sand underlying sandy loam. The soil was tested before planting the broccoli; $90 \mathrm{~kg} \cdot \mathrm{ha}^{-1}$ of $\mathrm{P}_{2} \mathrm{O}_{5}, 140 \mathrm{~kg} \cdot \mathrm{ha}^{-1}$ of $\mathrm{K}_{2} \mathrm{O}$ and $100 \mathrm{~kg} \cdot \mathrm{ha}^{-1}$ of $\mathrm{N}$ were applied before the soil preparation. Additionally, nitrogen $\left(100 \mathrm{~kg} \mathrm{ha}^{-1}\right)$ was applied in three doses during the growing season. The plants were watered when the soil water potential exceeded -0.04 MPa. The broccoli heads were harvested when they reached the maximum size and their buds were $2 \mathrm{~mm}$ in diameter. They were stored under the following conditions: humidity: $95 \%$ at $3{ }^{\circ} \mathrm{C}$ and $50 \%$ at 16 and $21{ }^{\circ} \mathrm{C}$, in the dark. The chemical analyses were made on a frozen material $\left(-20^{\circ} \mathrm{C}\right)$.

\section{Methods}

\section{Phenolic compounds}

The phenolics were extracted from the frozen broccoli heads that were homogenised in $80 \%$ methanol (sample weight: $8 \mathrm{~g}$ of broccoli; heating at a temperature of $80{ }^{\circ} \mathrm{C}$ for $2 \mathrm{~h}$ in $10 \mathrm{ml}$ of methanol). The content of phenolic compounds was determined by means of a Folin-Ciocalteu assay with gallic acid used as a standard [27]. The absorbance was measured using a Varian Cary 300 Bio UV-Visible spectrophotometer at $\lambda=765 \mathrm{~nm}$.

The concentration of phenolic acids (caffeic, ferulic, and sinapic) and flavonoids (quercetin and kaempferol) was determined after the accomplished alkaline and acid hydrolysis. The methanolic extract was treated with $2 \mathrm{M} \mathrm{NaOH}$ and boiled for 30 minutes. After acidification, the phenolics were extracted with diethyl ether. Then, the methanolic extract was treated with $6 \mathrm{M} \mathrm{HCl}$, boiled for 30 minutes, and once more extracted with diethyl ether. The combined extracts were dried and re-dissolved in $1 \mathrm{ml}$ of $80 \%$ ethanol before being injected into a HPLC column [12].

The HPLC analysis was made with a Waters Alliance 2695 Chromatograph coupled with a Waters 2996 Photodiode Array Detector. The chromatographic separation was carried out on an RP C-18 column, $250 \times 4 \mathrm{~mm} \times 5 \mu \mathrm{m}$ (at a temperature of $\left.20{ }^{\circ} \mathrm{C}\right)$, with an acetonitrile: $2 \%$ aqueous acetic acid mixture $(\mathrm{pH}=2)$ used as an elution phase (gradient). The mobile phase consisted of $\mathrm{A}$ (acetonitrile) and $\mathrm{B}$ (water and $2 \%$ acetic acid). The gradient elution was as follows: at the start: $100 \% \mathrm{~B} ; 0 \div 14 \mathrm{~min}$ : $90 \%$ B; $14 \div 30$ min: $90 \%$ B; $30 \div 45$ min: $82 \%$ B; $45 \div 55$ min: $100 \%$ A; $55 \div$ 60 min: $100 \%$ A; $60 \div 75$ min: $100 \% \mathrm{~B}$. The concentrations of phenolic acids were determined by means of an internal standard at wavelengths of $\lambda=280 \mathrm{~nm}$ (caffeic and 
sinapic acid) or $\lambda=320 \mathrm{~nm}$, and $280 \mathrm{~nm}$ (ferulic acid), whereas the wavelength of flavonoids was $\lambda=320 \mathrm{~nm}$. The compounds were identified by comparing the retention time of the peak under analysis with the retention time of the standard, and by adding a specific amount of the standard to the samples analysed as well as by repeating the analysis. The detection level was $1 \mu \mathrm{g} / \mathrm{g}$. The retention times of the assayed acids and flavonoids were as follows: caffeic acid - $26.19 \mathrm{~min}$; ferulic acid - $46.20 \mathrm{~min}$; sinapic acid - $48.00 \mathrm{~min}$; quercetin - $52.25 \mathrm{~min}$; and kaempferol - $53.13 \mathrm{~min}$.

The gallic, caffeic, ferulic, sinapic acids, quercetin, kaempferol, Folin-Ciocalteu's phenol reagent, sodium carbonate, $\mathrm{NaOH}$ and methanol were purchased from SigmaAldrich (St. Louis, MO, USA). The diethyl ether was purchase from Honeywell (Germany).

\section{Tocopherols}

Tocopherols were extracted from a frozen homogenised broccoli head (10 g) by means of $50 \mathrm{ml}$ of n-hexane according to the procedure as described by GliszczyńskaŚwigło et al. [11]; the n-hexane fractions were combined and evaporated to dryness in vacuum at $30^{\circ} \mathrm{C}$.

Prior to the HPLC analysis, the residue was dissolved in $2 \mathrm{ml}$ of 2-propanol. The tocopherols were determined with a Waters 2695 apparatus (Waters, Milford, MA, USA) with a Waters 2475 fluorescence detector at an emission wavelength of $325 \mathrm{~nm}$ and excitation of $295 \mathrm{~nm}$ with a Symmetry C18 column $(150 \mathrm{~mm} \times 3.9 \mathrm{~mm}, 5 \mu \mathrm{m})$. A mobile phase of acetonitrile and methanol $(1: 1, \mathrm{v} / \mathrm{v})$ was used at a flow rate of $1 \mathrm{~mL} / \mathrm{min}$. The detection limits for tocopherols were $10.0 \mathrm{ng} / \mathrm{g}$. The tocopherols were identified by comparing their retention times with the relevant standards. The external standard method was applied to the quantification of those compounds. Additionally, the Waters 2996 Photodiode Array Detector was utilized to identify the compounds on the basis of their absorption spectra.

\section{Statistical analysis}

All statistical analyses were performed using a Statistica software (StatSoft, Poland). The significance of the impact of temperature and duration of storage on the content of phenolic compounds and tocopherols was determined with the F-test. The differences among the mean values were estimated with the Duncan test at a significance level of $\mathrm{p}=0.05$.

\section{Results and discussion}

Tab. 1 - 4 show the results of the present study on the effect of short-term storage on the content of phenolic and tocopherols in broccoli heads. The study confirmed the presence of caffeic, ferulic and sinapic acids, quercetin, and kaempferol as well as of 
$\alpha$-, $\gamma$ - and $\delta$-tocophrol in the broccoli. Other authors also documented the presence of chlorogenic acid, p-coumaric acid, and benzoic acid, or glucose esters of those acids or other derivatives in broccoli heads $[30,25]$. Their reports show that a high variation occurs among the phenolics in broccoli. According to many researchers $[7,13,16,17$, 23 ], this fact can be attributed to numerous factors such as genotype, agronomic environment, maturity stage at the harvest, and postharvest treatment. In some studies the differences between plant organs were observed [7]. Borowski et al. [1] also reported the high variability within the same cultivar grown under the same agricultural and climatic conditions. The results of many research works indicate that bioactive, nutritional and organoleptic qualities of broccoli are strongly affected by the storage period and storage conditions [9, 31].

\section{Total phenolics}

Broccoli is known to have a high level of phenolics $[10,14]$. The content of total phenolics in a 'Tiburon' cv. of broccoli is presented in tab. 1 and expressed as mg of gallic acid equivalents (GAE) per $100 \mathrm{~g}$ fresh weight. In our study the content ranged from 1.68 to $7.28 \mathrm{mg} \mathrm{GAE} / 100 \mathrm{~g}$ f.w. A two-year study conducted by Koh et al. [16], showed that in fresh broccoli heads the amount of total phenolics was more wideranging: from 15.18 to $121.38 \mathrm{mg} \mathrm{GAE} / 100 \mathrm{~g}$ f.w.

Table 1. Content of total phenolics in broccoli heads during short-term storage

Tabela 1. Zawartość związków fenolowych ogółem w różach brokułu podczas krótkotrwałego przechowywania

\begin{tabular}{|c|c|c|c|c|c|}
\hline \multirow{3}{*}{$\begin{array}{c}\text { Storage } \\
\text { temperature } \\
\text { Temperatura } \\
\text { przechowywania } \\
{\left[{ }^{\circ} \mathrm{C}\right]}\end{array}$} & \multicolumn{5}{|c|}{ Day of storage / Dzień przechowywania } \\
\hline & 0 & 1 & 2 & 3 & 4 \\
\hline & \multicolumn{5}{|c|}{ Content of total phenolics / Ogólna zawartość fenoli [mg GAE/100 g f.w.] } \\
\hline 3 & \multirow{3}{*}{$1.68^{\mathrm{K}} \pm 0.10$} & $2.52^{\mathrm{J}} \pm 0.14$ & $3.37^{\mathrm{GH}} \pm 0.10$ & $4.00^{\mathrm{DE}} \pm 0.29$ & $4.71^{\mathrm{C}} \pm 0.19$ \\
\hline 16 & & $2.80^{\mathrm{IJ}} \pm 0.11$ & $3.80^{\mathrm{EF}} \pm 0.01$ & $4.31^{\mathrm{D}} \pm 0.12$ & $6.12^{\mathrm{B}} \pm 0.11$ \\
\hline 21 & & $3.00^{\mathrm{HI}} \pm 0.05$ & $3.45^{\mathrm{FG}} \pm 0.12$ & $4.82^{\mathrm{C}} \pm 0.05$ & $7.28^{\mathrm{A}} \pm 0.01$ \\
\hline
\end{tabular}

Explanatory notes / Objaśnienia:

Table shows mean values and standard deviations; $(\mathrm{n}=2) / \mathrm{W}$ tabeli przedstawiono wartości średnie \pm odchylenia standardowe.

All means denoted by different superscript letters differ statistically significantly at $\mathrm{p} \leq 0.05$ / Wszystkie wartości oznaczone różnymi literami w indeksie górnym różnią się statystycznie istotnie przy p $\leq 0,05$.

Kaur et al. [14] assayed eight broccoli cultivars for the total phenolic level and the values ranged from 19.6 to $41.4 \mathrm{mg}$ GAE/100 g f.w. Higher values were obtained by Singh et al. [26], Chu et al. [3] and Kevers et al. [15] $44.5 \div 82.9 \mathrm{mg} \mathrm{GAE} / 100$ g f.w., 
$101.6 \mathrm{mg} \mathrm{GAE} / 100 \mathrm{~g}$ f.w., and $127 \mathrm{mg} \mathrm{GAE} / 100 \mathrm{~g}$ f.w., respectively. Differences between the extraction procedures and the ways of expressing results can contribute to the array of contrasting results what proves that the comparison among the research studies might be very difficult $[14,24]$.

In the present study, changes were found in the content of total phenolics during storage. The lowest concentration of phenolics was detected at the $0^{\text {th }}$ day of storage; it was the highest after 4 days of storage (tab. 1). However, the concentration of those compounds was not affected by temperature. In addition, Kervers et al. [15] and Conversa et al. [5] found an increase in the level of phenolics in broccoli heads during storage. In the study by Zhan et al. [32], the content of total phenolics rose significantly in the broccoli heads exposed to light during storage (at 4 and $7^{\circ} \mathrm{C}$ ) and reached its peak, with a 1.6-fold increase, on the $7^{\text {th }}$ day of storage. Yet, it was constant in the heads stored in darkness.

Leja et al. [18] also confirmed the accumulation of total phenolics during storage. In their studies, an intense accumulation was observed at a temperature of $20^{\circ} \mathrm{C}$ from the first day of storage, while at a temperature of $5{ }^{\circ} \mathrm{C}$ - from the seventh day.

In the study conducted by Patras et al. [22], the content of phenolics in the unblanched broccoli samples increased significantly from the day when the accumulation was intense, i.e. in a period between the $0^{\text {th }}$ and $5^{\text {th }}$ day, and, then, it decreased. Lemoine et al. [19] obtained similar results. While comparing seven broccoli cultivars stored for 7, 14, and 21 days at $5{ }^{\circ} \mathrm{C}$, Conversa et al. [5] found the unchanged content of total phenolics (except for two cultivars) after 7 days of storage; but, after 14 days of storage, they reported an increase in all but one of the cultivars they analyzed.

Fernandez-Leon et al. [9] also found an increase in the content of total phenolics after 13 days of cold-storing the samples in a controlled atmosphere $\left(1 \div 2{ }^{\circ} \mathrm{C}, 85 \div\right.$ $90 \% \mathrm{RH}, 10 \% \mathrm{O}_{2}$ and $5 \% \mathrm{CO}_{2}$ ). On the other hand, as regards the broccoli heads stored at $1 \div 2{ }^{\circ} \mathrm{C}$ and at $85 \div 90 \% \mathrm{RH}$ (control samples) and the broccoli heads treated with Smart-Fresh ${ }^{\mathrm{TM}}$, a sharp decrease was reported.

According to Page et al. [21] and Costa et al. [6], the increase in the content of phenolics during storage can result from of the senescing of broccoli heads.

Phenolic acids

Under the present study, it was found that the fresh broccoli heads had the highest content of caffeic acid, the content of sinapic acid therein was the second-highest and that of the ferulic acid - the third-highest (tab. 2). Vallejo et al. [30] obtained different results. They reported that the sinapic acid had the highest content, the ferulic acid had the second-highest content, and the caffeic acid derivatives - the third-highest. 
Table 2. Content of phenolic acids in broccoli heads during short-term storage

Tabela 2. Zawartość kwasów fenolowych w różach brokułu podczas krótkotrwałego przechowywania

\begin{tabular}{|c|c|c|c|c|c|}
\hline \multirow{3}{*}{$\begin{array}{l}\text { Storage temperature } \\
\text { Temperatura } \\
\text { przechowywania }\left[{ }^{\circ} \mathrm{C}\right]\end{array}$} & \multicolumn{5}{|c|}{ Day of storage / Dzień przechowywania } \\
\hline & 0 & 1 & 2 & 3 & 4 \\
\hline & \multicolumn{5}{|c|}{ Caffeic acid / Kwas kawowy [ $\mu \mathrm{g} / \mathrm{g}$ f.w.] } \\
\hline 3 & \multirow{3}{*}{$\begin{array}{c}8.76^{\mathrm{E}} \pm \\
1.19\end{array}$} & $9.03^{\mathrm{E}} \pm 1.09$ & $10.01^{\mathrm{DE}} \pm 1.07$ & $12.31^{\mathrm{BC}} \pm 0.47$ & $12.86^{\mathrm{B}} \pm 0.27$ \\
\hline 16 & & $8.58^{\mathrm{DE}} \pm 1.77$ & $11.23^{\mathrm{BCD}} \pm 0.88$ & $12.96^{\mathrm{B}} \pm 0.51$ & $16.24^{\mathrm{A}} \pm 0.71$ \\
\hline \multirow[t]{2}{*}{21} & & $10.33^{\mathrm{CDE}} \pm 2.12$ & $12.44^{\mathrm{B}} \pm 2.45$ & $14.89^{\mathrm{A}} \pm 1.89$ & $16.68^{\mathrm{A}} \pm 0.78$ \\
\hline & \multicolumn{5}{|c|}{ Ferulic acid / Kwas ferulowy [ $\mu \mathrm{g} / \mathrm{g}$ f.w.] } \\
\hline 3 & \multirow{3}{*}{$\begin{array}{c}6.48^{\mathrm{E}} \pm \\
0.01\end{array}$} & $7.00^{\mathrm{E}} \pm 0.24$ & $11.28^{\mathrm{CDE}} \pm 2.34$ & $15.15^{\mathrm{BCD}} \pm 4.81$ & $20.90^{\mathrm{AB}} \pm 3.61$ \\
\hline 16 & & $6.97^{\mathrm{E}} \pm 0.02$ & $9.56^{\mathrm{DE}} \pm 1.43$ & $17.32^{\mathrm{BC}} \pm 0.73$ & $25.00^{\mathrm{A}} \pm 1.10$ \\
\hline \multirow[t]{2}{*}{21} & & $8.98^{\mathrm{DE}} \pm 0.15$ & $12.13^{\mathrm{CDE}} \pm 2.0$ & $19.34^{\mathrm{AB}} \pm 1.44$ & $21.97^{\mathrm{AB}} \pm 3.11$ \\
\hline & \multicolumn{5}{|c|}{ Sinapic acid / Kwas synapinowy [ $\mu \mathrm{g} / \mathrm{g}$ f.w.] } \\
\hline 3 & \multirow{3}{*}{$\begin{array}{c}7.07^{\mathrm{G}} \pm \\
1.01\end{array}$} & $10.23^{\mathrm{F}} \pm 0.13$ & $13.11^{\mathrm{EF}} \pm 0.65$ & $14.67^{\mathrm{CDE}} \pm 0.42$ & $16.52^{\mathrm{CD}} \pm 0.51$ \\
\hline 16 & & $13.84^{\mathrm{DE}} \pm 0.73$ & $16.14^{\mathrm{CDE}} \pm 0.71$ & $19.93^{\mathrm{AB}} \pm 0.63$ & $21.12^{\mathrm{A}} \pm 0.74$ \\
\hline 21 & & $13.97^{\mathrm{DE}} \pm 0.51$ & $15.65^{\mathrm{CDE}} \pm 0.58$ & $17.76^{\mathrm{BC}} \pm 1.45$ & $21.61^{\mathrm{A}} \pm 2.44$ \\
\hline
\end{tabular}

Explanatory notes / Objaśnienia:

Table shows mean values and standard deviations; $(\mathrm{n}=2) / \mathrm{W}$ tabeli przedstawiono wartości średnie \pm odchylenia standardowe.

Means denoted by different superscript letters differ statistically significantly at $\mathrm{p} \leq 0.05$, for each acid separately/ Wartości oznaczone różnymi literami w indeksie górnym różnią się statystycznie istotnie przy $\mathrm{p} \leq 0,05$, oddzielnie dla każdego kwasu.

The concentration of caffeic acid ranged from 8.76 to $16.68 \mu \mathrm{g} / \mathrm{g}$ f.w. The content of caffeic acid was the lowest in the fresh broccoli heads (on the $0^{\text {th }}$ day of storage) and amounted to $8.76 \mu \mathrm{g} / \mathrm{g}$ f.w. In the study conducted by Sikora et al. [25], the fresh broccoli heads contained $4 \mu \mathrm{g} / \mathrm{g}$ f.w. In the study by Vallejo et al. [29], the content of caffeic acid was strongly related to the broccoli cultivar and ranged from 7.6 to $38.2 \mu \mathrm{g} / \mathrm{g}$ f.w.

The one day storage did not affect the concentration of caffeic acid in the broccoli heads at any of the temperatures applied. At $3{ }^{\circ} \mathrm{C}, 16^{\circ} \mathrm{C}$, and $21^{\circ} \mathrm{C}$, there was a significant increase in the concentration documented on the second (except for the temperature of $3{ }^{\circ} \mathrm{C}$ ), third, and fourth day of storage, respectively, compared to the day of harvesting. Apart from the first day of storage, on every following day, there were higher concentrations of caffeic acid observed at all the storage temperatures compared to the control samples. Our results are in contrast with those of Vallejo et al. [31] who showed large loss rates of caffeic acid derivatives during storage. 
The concentration of ferulic acid ranged from 6.48 to $25.00 \mu \mathrm{g} / \mathrm{g}$ f.w. In the studies conducted by Sikora et al. [25] and Pek et al. [23], the content of ferulic acid was $19.8 \mu \mathrm{g} / \mathrm{g}$ f.w. and $0.6 \div 24.3 \mu \mathrm{g} / \mathrm{g}$ f.w., respectively.

While storing the broccoli heads for one and two days at any of the temperatures indicated, no impact of that storage period was found on the concentration of ferulic acid therein. But on the third day of storing them at any of the temperatures applied, a significant increase was documented in the concentration of ferulic acid. An increase in the storage temperature did not affect the concentration of ferulic acid on any respective day of storage.

The derivatives of sinapic acid are characteristic compounds in the Brassicaceae family and, mainly owing to their antioxidant activity, those compounds are suggested for potential use in food processing, cosmetics, and the pharmaceutical industry [20]. Broccoli heads were reported to contain more than $100 \mu \mathrm{g} / \mathrm{g}$ of sinapic acid bound in its esters and conjugates [2]. Vallejo et al. [29] obtained a lower content of sinapic acid, i.e. $25.4 \div 82.5 \mu \mathrm{g} / \mathrm{g}$ f.w. In the studies conducted by Sikora et al. [25] and Fernandez-Leon et al. [8], the content of sinapic acid was $29.5 \mu \mathrm{g} / \mathrm{g}$ f.w. and $6.4 \div$ $12.5 \mu \mathrm{g} / \mathrm{g}$ f.w., respectively. Pek et al. [23] obtained a content of that acid ranging from 6.8 to $43.4 \mu \mathrm{g} / \mathrm{g}$ f.w and it depended on the treatment and harvest date.

In the present study, the concentration of sinapic acid ranged from 7.07 to $21.61 \mu \mathrm{g} / \mathrm{g}$ f.w. On all of the days of experiment and at all of the storage temperatures, higher concentrations of sinapic acid were found in the samples stored compared to those in the non-stored control samples. There were also changes in the concentration level related to the increase in the temperature (except for the second day of storage). Fernandez-Leon et al. [9] observed a degradation of sinapic acid after 9 days of storage. In the research performed by Vallejo et al. [31], high losses of the amount of sinapic acid derivatives were also observed.

\section{Quercetin and kaempferol}

The concentration of quercetin ranged from 9.23 to $18.74 \mu \mathrm{g} / \mathrm{g}$ f.w. (tab. 3). According to what many researchers earlier documented [17, 25], kaempferol prevailed and its concentration ranged from 50.33 to $67.99 \mu \mathrm{g} / \mathrm{g}$ f.w. In contrast, Kevers et al. [15], and Koh et al. [16] reported a higher content of quercetin than that of kaempferol.

Higher or similar concentrations of those flavonoids were confirmed by other experiments $[13,16]$. Much lower concentrations were obtained by Kurilich et al. [17]. According to them, the differences observed in the levels of flavonoids could be attributed to the extraction methods used. 
Table 3. Content of quercetin and kaempferol in broccoli heads during short-term storage

Tabela 3. Zawartość kwercetyny i kemferolu w różach brokułu podczas krótkotrwałego przechowywania

\begin{tabular}{|c|c|c|c|c|c|}
\hline \multirow{3}{*}{$\begin{array}{c}\text { Storage tempe- } \\
\text { rature } \\
\text { Temperatura } \\
\text { przechowywania } \\
{\left[{ }^{\circ} \mathrm{C}\right]}\end{array}$} & \multicolumn{5}{|c|}{ Day of storage / Dzień przechowywania } \\
\hline & 0 & 1 & 2 & 3 & 4 \\
\hline & \multicolumn{5}{|c|}{ Quercetin / Kwercetyna [ $\mu \mathrm{g} / \mathrm{g}$ f.w.] } \\
\hline 3 & \multirow{3}{*}{$9.23^{\mathrm{F}} \pm 0.28$} & $12.01^{\mathrm{DEF}} \pm 1.97$ & $16.04^{\mathrm{ABC}} \pm 0.51$ & $15.30^{\mathrm{BC}} \pm 2.21$ & $18.74^{\mathrm{A}} \pm 1.66$ \\
\hline 16 & & $9.48^{\mathrm{F}} \pm 2.11$ & $12.01^{\mathrm{DEF}} \pm 0.89$ & $14.23^{\mathrm{CD}} \pm 0.56$ & $17.95^{\mathrm{AB}} \pm 1.09$ \\
\hline \multirow[t]{2}{*}{21} & & $11.29^{\mathrm{EF}} \pm 0.39$ & $13.30^{\mathrm{CDE}} \pm 0.69$ & $14.41^{\mathrm{CD}} \pm 0.04$ & $17.28^{\mathrm{AB}} \pm 0.37$ \\
\hline & \multicolumn{5}{|c|}{ Kaempferol / Kemferol [ $\mu$ g/g f.w.] } \\
\hline 3 & \multirow{3}{*}{$50.33^{\mathrm{F}} \pm 3.08$} & $51.09^{\mathrm{F}} \pm 1.18$ & $56.46^{\mathrm{DE}} \pm 1.55$ & $63.60^{\mathrm{BC}} \pm 2.53$ & $66.56^{\mathrm{AB}} \pm 1.58$ \\
\hline 16 & & $52.18^{\mathrm{F}} \pm 3.06$ & $57.92^{\mathrm{D}} \pm 1.99$ & $63.03^{\mathrm{BC}} \pm 0.95$ & $66.49^{\mathrm{AB}} \pm 1.92$ \\
\hline 21 & & $52.60^{\mathrm{EF}} \pm 1.68$ & $59.84^{\mathrm{CD}} \pm 2.17$ & $63.91^{\mathrm{ABC}} \pm 3.02$ & $67.99^{\mathrm{A}} \pm 2.09$ \\
\hline
\end{tabular}

Explanatory notes / Objaśnienia:

Table shows mean values and standard deviations; $(n=2) / W$ tabeli przedstawiono wartości średnie \pm odchylenia standardowe.

All means denoted by different superscript letters differ statistically significantly at $p \leq 0.05$ / Wszystkie wartości oznaczone różnymi literami w indeksie górnym różnią się statystycznie istotnie przy $\mathrm{p} \leq 0,05$.

In the study conducted by Kałużewicz et al. [13], the content of quercetin and kaempferol fluctuated throughout the storage period, whereas Kevers et al. [15] reported a relatively stable content of those flavonoids. In our study, there were no differences between the concentrations of quercetin and kaempferol, no matter what temperature was applied and what day of the experiment it was. An increase was observed only when compared with the control sample (the 0 day of storage). Our previous study indicated that the contents of quercetin and kaempferol increased along with the increase in the storage temperature [13].

\section{Tocopherols}

According to Podsędek [24], vitamin E consists of four tocopherols $(\alpha-, \beta$-, $\gamma$ - and $\delta$-T) and the corresponding ( $\alpha$-, $\beta$-, $\gamma$ - and $\delta$-T3) tocotrienols. In Brassica spp., both the $\alpha$ - and the $\beta$-tocopherol were identified at significant levels [12, 17]. Many authors show that $\alpha$-tocopherol is the predominant tocopherol in all Brassica vegetables and broccoli is the best source of lipid-soluble antioxidants $[4,24,26]$. Literature data on the content of tocopherols found in broccoli vary greatly and this fact could be ascribed to diverse cultivars and various conditions of growing them [24]. 
Table 4. Content of tocopherols in broccoli heads during short-term storage

Tabela 4. Zawartość tokoferoli w różach brokułu podczas krótkotrwałego przechowywania

\begin{tabular}{|c|c|c|c|c|c|}
\hline \multirow{3}{*}{\begin{tabular}{|c|} 
Storage tempe- \\
rature \\
Temperatura \\
przechowywania \\
{$\left[{ }^{\circ} \mathrm{C}\right]$} \\
\end{tabular}} & \multicolumn{5}{|c|}{ Day of storage / Dzień przechowywania } \\
\hline & 0 & 1 & 2 & 3 & 4 \\
\hline & \multicolumn{5}{|c|}{$\alpha$-tocopherol / $\alpha$-tokoferol [ $\mu \mathrm{g} / \mathrm{g}$ f.w.] } \\
\hline 3 & \multirow{3}{*}{$39.02^{\mathrm{ABC}} \pm 1.95$} & $41.00^{\mathrm{ABC}} \pm 0.06$ & $30.10^{\mathrm{BCD}} \pm 3.79$ & $28.75^{\mathrm{CD}} \pm 3.20$ & $24.42^{\mathrm{DE}} \pm 3.67$ \\
\hline 16 & & $42.34^{\mathrm{AB}} \pm 3.50$ & $30.55^{\mathrm{BCD}} \pm 1.32$ & $19.65^{\mathrm{DEF}} \pm 6.26$ & $11.29^{\mathrm{EF}} \pm 2.79$ \\
\hline \multirow[t]{2}{*}{21} & & $44.20^{\mathrm{A}} \pm 2.29$ & $21.12^{\mathrm{DEF}} \pm 6.38$ & $20.13^{\mathrm{DEF}} \pm 6.81$ & $8.53^{\mathrm{F}} \pm 1.23$ \\
\hline & \multicolumn{5}{|c|}{$\gamma$-tocopherol $/ \gamma$-tokoferol [ $\mu \mathrm{g} / \mathrm{g}$ f.w.] } \\
\hline 3 & \multirow{3}{*}{$15.98^{\mathrm{AB}} \pm 0.62$} & $9.09^{\mathrm{BCDE}} \pm 0.91$ & $7.13^{\mathrm{CDE}} \pm 1.81$ & $5.87^{\mathrm{CDE}} \pm 1.39$ & $4.96^{\mathrm{DE}} \pm 0.68$ \\
\hline 16 & & $16.73^{\mathrm{A}} \pm 0.28$ & $15.92^{\mathrm{AB}} \pm 0.28$ & $10.55^{\mathrm{ABCD}} \pm 2.33$ & $5.37^{\mathrm{CDE}} \pm 1.02$ \\
\hline \multirow[t]{2}{*}{21} & & $12.42^{\mathrm{ABC}} \pm 1.40$ & $10.29^{\mathrm{ABCD}} \pm 2.28$ & $7.69^{\mathrm{CDE}} \pm 1.17$ & $2.58^{\mathrm{E}} \pm 0.04$ \\
\hline & \multicolumn{5}{|c|}{$\delta$-tocopherol / $\delta$-tokoferol [ $\mu \mathrm{g} / \mathrm{g}$ f.w.] } \\
\hline 3 & \multirow{3}{*}{$1.17^{\mathrm{A}} \pm 0.08$} & $0.50^{\mathrm{CDE}} \pm 0.06$ & $0.44^{\mathrm{DE}} \pm 0.07$ & $0.46^{\mathrm{CDE}} \pm 0.04$ & $0.34^{\mathrm{E}} \pm 0.21$ \\
\hline 16 & & $1.06^{\mathrm{AB}} \pm 0.02$ & $0.86^{\mathrm{ABCD}} \pm 0.09$ & $0.86^{\mathrm{ABCD}} \pm 0.28$ & $0.62^{\mathrm{BCDE}} \pm 0.05$ \\
\hline \multirow[t]{2}{*}{21} & & $0.83^{\mathrm{ABCD}} \pm 0.01$ & $0.94^{\mathrm{ABC}} \pm 0.16$ & $0.83^{\mathrm{ABCD}} \pm 0.21$ & $0.57^{\mathrm{CDE}} \pm 0.25$ \\
\hline & \multicolumn{5}{|c|}{ Total tocopherols / Suma tokoferoli [ $\mu \mathrm{g} / \mathrm{g}$ f.w.] } \\
\hline 3 & \multirow{3}{*}{$56.16^{\mathrm{A}} \pm 1.37$} & $50.60^{\mathrm{AB}} \pm 0.82$ & $37.67^{\mathrm{BC}} \pm 5.56$ & $35.30^{\mathrm{BCD}} \pm 4.46$ & $29.72^{\mathrm{CDE}} \pm 4.24$ \\
\hline 16 & & $60.13^{\mathrm{A}} \pm 3.21$ & $47.33^{\mathrm{ABC}} \pm 1.08$ & $30.96^{\mathrm{CD}} \pm 8.68$ & $17.27^{\mathrm{DE}} \pm 3.83$ \\
\hline 21 & & $57.44^{\mathrm{A}} \pm 3.69$ & $32.35^{\mathrm{BCD}} \pm 8.73$ & $28.65^{\mathrm{CDE}} \pm 8.08$ & $11.68^{\mathrm{E}} \pm 1.06$ \\
\hline
\end{tabular}

Explanatory notes / Objaśnienia:

Table shows mean values and standard deviations; $(\mathrm{n}=2) / \mathrm{W}$ tabeli przedstawiono wartości średnie \pm odchylenia standardowe.

All means denoted by different superscript letters differ statistically significantly at $\mathrm{p} \leq 0.05$ / Wszystkie wartości oznaczone różnymi literami w indeksie górnym różnią się statystycznie istotnie przy p $\leq 0,05$.

In the present study, the $\alpha-\beta$ - and $\delta$-tocopherols were identified in the fresh broccoli heads and in the heads stored at different temperatures $\left(3{ }^{\circ} \mathrm{C}, 16{ }^{\circ} \mathrm{C}\right.$, and $21{ }^{\circ} \mathrm{C}$ ) for 4 days (tab. 4). The content of $\alpha$-tocopherol was predominant and ranged from 70.4 to $81.0 \%$ of total tocopherols. A similar result (79\%) was obtained by Ibrahim and Juvik [12]. The percent content of $\beta$ - and $\delta$-tocopherols in all the tocopherols was $18.0 \div 27.8$ and $1.0 \div 1.76 \%$, respectively, which was confirmed by other researchers [11].

In the available literature, there is little information about the effect of storage temperature on the content of tocopherols. During storage at $3{ }^{\circ} \mathrm{C}$, it was found that the stability of total tocopherols was good $\left(41.3 \%\right.$ of reduction). During storage at $21{ }^{\circ} \mathrm{C}$, the stability was the lowest: $79.7 \%$ of reduction. The highest concentration of tocoph- 
erols was reported at $16{ }^{\circ} \mathrm{C}$ on the first day of storage $(60.13 \mu \mathrm{g} / \mathrm{g}$ f.w. $)$ and the lowest at $21{ }^{\circ} \mathrm{C}$ on the fourth day of storage $(11.68 \mu \mathrm{g} / \mathrm{g}$ f.w.). Compared to the control samples (the 0 day of storage), a slight increase in the content of $\alpha$-tocopherol observed in the present study is most likely the result of better availability of those compounds for extraction.

\section{Conclusion}

1. The highest content of phenolics was observed at the end of storage.

2. The content of kaempferol was much higher than the content of quercetin in the broccoli heads.

3. On the harvest day of broccoli, the highest tocopherol content was reported.

4. Of the contents of total tocopherols, the content of alfa tocopherol was predominant.

5. The contents of tocopherols were characterised by the highest stability at the lowest temperature.

\section{References}

[1] Borowski J., Szajdek A., Borowska E.J., Ciska E., Zieliński H.: Content of selected bioactive components and antioxidant properties of broccoli (Brassica oleracea L.). Eur. Food Res. Technol., 2008, 226 (3), 459-465.

[2] Clifford M.N.: Chlorogenic acids and other cinnamates - nature, occurrence and dietary burden. J. Sci. Food Agr., 2000, 80 (7), 1033-1043.

[3] Chu Y.F., Sun J., Wu X., Liu R.H.: Antioxidant and antiproliferative activities of common vegetables. J. Agric. Food Chem., 2002, 50 (23), 6910-6916.

[4] Chun J., Lee J., Ye L., Exler J., Eitenmiller R.R.: Tocopherol and tocotrienol contents of raw and processed fruits and vegetables in the United States diet. J. Food Compos. Anal., 2006, 19 (2-3), 196-204.

[5] Conversa G., Bonasia A., Lazzizera C., Elia A.: Changes in biochemical and qualitative properties in fresh-cut broccoli genotypes during storage. Acta Hortic., 2013, 1005, 641-647.

[6] Costa L., Vicente A.R., Civello P.M., Chaves A.R., Martinez G.A.: UV-C treatment delays postharvest senescence in broccoli florets. Postharvest Biol. Tec., 2006, 39, 204-210.

[7] Długosz-Grochowska O., Leja M., Grabowska A., Kunicki E.: The effect of preliminary chilling of broccoli transplants on some antioxidative parameters. Folia Hort., 2012, 24 (2), 131-139.

[8] Fernandez-Leon M.F., Fernandez-Leon A.M., Lozano M., Ayuso M.C., Gonzalez-Gomez D.: Identification, quantification and comparison of the principal bioactive compounds and external quality parameters of two broccoli cultivars. J. Funct. Foods, 2012, 4 (2), 465-473.

[9] Fernandez-Leon M.F., Fernandez-Leon A.M., Lozano M., Ayuso M.C., Gonzalez-Gomez D.: Different postharvest strategies to preserve broccoli quality during storage and shelf life: Controlled atmosphere and 1-MCP. Food Chem., 2013, 138 (1), 564-573.

[10] Gawlik-Dziki U.: Fenolokwasy jako bioaktywne składniki żywności. Żywność. Nauka. Technologia. Jakość, 2004, 4 (41) Supl., 29-40.

[11] Gliszczyńska-Świgło A., Ciska E., Pawlak-Lemańska K., Chmielewski J., Borkowski T., Tyrakowska B.: Changes in the content of health-promoting compounds and antioxidant activity of broccoli after domestic processing. Food Addit. Contam., 2006, 23 (11), 1088-1098. 
[12] Gliszczyńska-Świgło A., Kałużewicz A., Lemańska K., Knaflewski M., Tyrakowska B.: The effect of solar radiation on the flavonol content in broccoli inflorescence. Food Chem., 2007, 100 (1), 241245.

[13] Ibrahim K.E., Juvik J.A.: Feasibility for improving phytonutrient content in vegetable crops using conventional breeding strategies: Case study with carotenoids and tocopherols in sweet corn and broccoli. J. Agric. Food Chem., 2009, 57 (11), 4636-4644.

[14] Kałużewicz A., Gliszczyńska-Świgło A., Klimczak I., Lisiecka J., Tyrakowska B., Knaflewski M.: The influence of short-term storage on the content of flavonoids and vitamin $\mathrm{C}$ in broccoli. Europ. J. Hort. Sci., 2012, 77 (3), 137-143.

[15] Kaur C., Kumar K., Anil D., Kapoor H.C.: Variations in antioxidant activity in broccoli (Brassica oleracea L.) cultivars. J. Food Biochem., 2007, 31 (5), 621-638.

[16] Kevers C., Falkowski M., Tabart J., Defraigne J.O., Dommes J., Pincemail J.: Evolution of antioxidant capacity during storage of selected fruits and vegetables. J. Agric. Food Chem., 2007, 55 (21), 8596-8603.

[17] Koh E., Wimalasiri K.M.S., Chassy A.W., Mitchell A.E.: Content of ascorbic acid, quercetin, kaempferol and total phenolics in commercial broccoli. J. Food Compos. Anal., 2009, 22 (7-8), 637643.

[18] Kurilich A.C., Jeffery E.H., Juvik J.A., Wallig M.A., Klein B.P.: Antioxidant capacity of different broccoli (Brassica oleracea) genotypes using the oxygen radical absorbance capacity (ORAC) assay. J. Agric. Food Chem., 2002, 50 (18), 5053-5057.

[19] Leja M., Mareczek A., Starzyńska A., Rożek S.: Antioxidant ability of broccoli flower buds during short-term storage. Food Chem., 2001, 72 (2), 219-222.

[20] Lemoine M.L., Civello P., Chaves A., Martinez G.: Hot air treatment delays senescence and maintains quality of fresh-cut broccoli florets during refrigerated storage. LWT-Food Sci. Technol., 2009, 42 (6), 1076-1081.

[21] Nićiforović N., Abramović H.: Sinapic acid and its derivatives: natural sources and bioactivity. Compr. Rev. Food. Sci. F., 2014, 13 (1), 34-51.

[22] Page T., Griffiths G., Buchanan-Wollaston V.: Molecular and biochemical characterization of postharvest senescence in broccoli. Plant Physiol., 2001, 125, 718-727.

[23] Patras A., Tiwari B.K., Brunton N.P.: Influence of blanching and low temperature preservation strategies on antioxidant activity and phytochemical content of carrots, green beans and broccoli. LWT-Food Sci. Technol., 2011, 44 (1), 299-306.

[24] Pek Z., Daood H., Nagyne M.G., Berki M., Tothne M.M., Nemenyi A., Helyes L.: Yield and phytochemical compounds of broccoli as affected by temperature, irrigation, and foliar sulfur supplementation. HortScience, 2012, 47 (11), 1646-1652.

[25] Podsędek A.: Natural antioxidants and antioxidant capacity of Brassica vegetables: A review. LWTFood Sci. Technol., 2007, 40 (1), 1-11.

[26] Sikora E., Cieślik E., Filipiak-Florkiewicz A., Leszczyńska T.: Effect of hydrothermal processing on phenolic acids and flavonols contents in selected brassica vegetables. Acta Sci. Pol., Technol. Aliment., 2012, 11 (1), 45-51.

[27] Singh J., Upadhyay A.K., Prasad K., Bahadur A., Rai M.: Variability of carotenes, vitamin C, E and phenolics in Brassica vegetables. J. Food Compos. Anal., 2007, 20 (2), 106-112.

[28] Singleton V.L., Rossi J.A.: Colorimetry of total phenolics witch phosphomolybdic-phosphotungstics acid reagents. Am. J. Enol. Vitic., 1965, 16 (3), 144-158.

[29] Szydłowska A., Czarniecka-Skubina E.: Wpływ sposobu gotowania i przechowywania po ugotowaniu na temperaturę, wydajność i jakość sensoryczną brokułów. Żywność. Nauka. Technologia. Jakość, 2006, 1 (46), 117-132.

[30] Vallejo F., Tomas-Barberan F.A., Garcia-Viguera C.: Potential bioactive compounds in health promotion from broccoli cultivars grown in Spain. J. Sci. Food Agr., 2002, 82 (11), 1293-1297.

[31] Vallejo F., Tomas-Barberan F.A., Garcia-Viguera C.: Effect of climatic and sulphur fertilisation conditions, on phenolic compounds and vitamin $\mathrm{C}$, in the inflorescences of eight broccoli cultivars. Eur. Food Res. Technol., 2003 , 216 (5), 395-401. 
[32] Vallejo F., Tomas-Barberan F.A., Garcia-Viguera C.: Health-promoting compounds in broccoli as influenced by refrigerated transport and retail sale period. J. Agric. Food Chem., 2003, 51 (10), 3029-3034.

[33] Zhan L., Hu J., Li Y., Pang L.: Combination of light exposure and low temperature in preserving quality and extending shelf-life of fresh-cut broccoli (Brassica oleracea L.). Postharvest Biol. Tec., 2012, 72, 76-81.

\title{
ZMIANY SKŁADU FENOLI I TOKOFEROLI W RÓŻACH BROKULU W TRAKCIE KRÓTKOTRWALEGO PRZECHOWYWANIA
}

\author{
Streszczenie
}

Brokuł (Brassica oleracea L. var. italica) zawiera liczne związki biologicznie aktywne. Ich poziom ulega jednak zmianie w trakcie przetwarzania i przechowywania.

Przedmiotem badań było określenie wpływu krótkotrwałego przechowywania róż brokułu $(1 \div 4$ dni) w różnych temperaturach $\left(3,6\right.$ i $\left.21{ }^{\circ} \mathrm{C}\right)$ na zawartość kwasów fenolowych, wybranych flawonoidów (kwercetyny i kemferolu) oraz tokoferoli. Brokuły były zbierane jesienią, kiedy róże osiągnęły swoje maksymalne rozmiary, a ich pączki wynosiły około $2 \mathrm{~mm}$.

Zawartość fenoli i tokoferoli zależała od czasu przechowywania róż. Najmniejszą zawartość fenoli stwierdzono tuż po zbiorze, a największą - po 4 dniach przechowywania. Na zawartość tych składników nie miała jednak wpływu temperatura przechowywania. Wśród badanych kwasów fenolowych stwierdzono największą zawartość kwasu kawowego, następnie synapinowego i ferulowego. Zawartość kemferolu w różach brokułu była większa niż zawartość kwercetyny. Nie było różnic pod względem zawartości kemferolu i kwercetyny w poszczególnych temperaturach przechowywania, w każdym dniu badań. Wzrost obserwowano tylko $\mathrm{w}$ porównaniu $\mathrm{z}$ próbą kontrolną (dzień 0 ). Dominującym tokoferolem w różach brokułu był $\alpha$-tokoferol. Najmniejszy ubytek sumy tokoferoli uzyskano podczas przechowywania w temperaturze $3{ }^{\circ} \mathrm{C}$, a największy - w temperaturze $21^{\circ} \mathrm{C}$.

Słowa kluczowe: Brassica oleracea L. var. italica, HPLC, fenole, tokoferole, przechowywanie, temperatura 